\title{
The Missing Dimension of the Political Resource
}

\section{Curse Debate}

\author{
Ranjit Lall|* \\ Forthcoming, Comparative Political Studies
}

\begin{abstract}
Given the methodological sophistication of the debate over the "political resource curse" $^{\prime \prime}$ the purported negative relationship between natural resource wealth (in particular oil wealth) and democracy - it is surprising that scholars have not paid more attention to the basic statistical issue of how to deal with missing data. This article highlights the problems caused by the most common strategy for analyzing missing data in the political resource curse literature - listwise deletion - and investigates how addressing such problems through the best-practice technique of multiple imputation affects empirical results. I find that multiple imputation causes the results of a number of influential recent studies to converge on a key common finding: a political resource curse does exist, but only since the widespread nationalization of petroleum industries in the 1970s. This striking finding suggests that much of the controversy over the political resource curse has been caused by a neglect of missing-data issues.
\end{abstract}

*Department of Government, Harvard University. For excellent comments and advice, I would like to thank Jeffry Frieden, Adam Glynn, James Honaker, Gary King, Walter Mattli, Margaret Roberts, Beth Simmons, Arthur Spirling, and the editors and three anonymous reviewers of Comparative Political Studies. I would also like to express my gratitude to Erica Frantz, Barbara Geddes, Kristopher Ramsay, and Joseph Wright for generously sharing data with me. 


\section{Introduction}

The debate over the existence of a so-called "political resource curse" - a negative relationship between natural resource wealth (in particular oil wealth) and democracy - has attained a high degree of methodological sophistication in recent years. It is thus surprising that contributors to this debate have not paid more attention to one of the most basic issues in the statistical analysis of cross-national political and economic data, namely, how to handle missing values. Datasets used to examine the political resource curse are often highly incomplete; indeed, I later show that levels of missingness in such datasets tend to be markedly higher than in other areas of quantitative comparative politics research. Nevertheless, analysts continue to deal with such values using the adhoc technique of listwise deletion - that is, to omit observations with missing values on any variable - which is known to produce inefficient and often biased statistical inferences in the typical conditions of applied empirical research.1

This article draws attention to the methodological problems caused by the use of listwise deletion in statistical analyses of the political resource curse and examines how addressing such problems through the best-practice technique of multiple imputation affects empirical results. I argue that, in addition to being inefficient, listwise deletion tends to produce biased inferences in such analyses because the distribution of missing values is not completely random. Most notably, authoritarian states are more likely to have incomplete data, causing listwise deletion to yield samples that are skewed toward the most democratic nations in the dataset - a selection problem that I call pro-democracy bias. Multiple imputation, which has long been recommended by statisticians and is now

\footnotetext{
${ }^{1}$ For instance, 27 of the 29 empirical studies included in Ahmadov's (2013) recent meta-analysis of the political resource curse employ listwise deletion as their primary missing-data method. The remaining two studies employ another ad-hoc and typically biased technique (linear interpolation in one case and a combination of linear interpolation, mean substitution, and zero imputation in the other). Worryingly, more than half of the studies - all of which employ listwise deletion - are not explicit about how they deal with missing data.
} 
emerging as the principal alternative to listwise deletion in many areas of the social and natural sciences, involves replacing each missing cell with multiple values based on information contained in the observed portion of the dataset $\left.\right|^{2}$ By utilizing all observed values, keeping incomplete observations in the sample, and preserving key relationships in the data, it both produces considerably more efficient inferences than listwise deletion and — crucially — avoids selection problems such as pro-democracy bias.

The reexamination reveals that multiple imputation alters the results of a number of prominent recent studies in ways that present a strikingly coherent, unified picture of the political resource curse. I focus on two important ongoing debates in the literature 3 The first concerns the extent to which existing statistical evidence for a political resource curse is plagued by omitted variable bias and other sources of endogeneity 44 I find that multiple imputation challenges Haber and Menaldo's (2011) influential conclusion that oil wealth is not negatively related to changes in democracy once we control for country fixed effects (and other sources of unobserved heterogeneity). Rather, it supports Andersen and Ross's (2014) claim that Haber and Menaldo's analysis does provide evidence of a negative relationship, but only after the widespread nationalization of petroleum industries in the 1970s, which enabled governments to seize control of oil rents. In addition, it corroborates the results of Ramsay's (2011) instrumental variables analysis of the political resource curse - an alternative strategy for addressing endogeneity - which,

\footnotetext{
${ }^{2}$ According to van Buuren (2012), multiple imputation is "now accepted as the best general method to deal with incomplete data in many fields" (p. 25). For statistics on the rapid growth of the applied literature on multiple imputation in recent decades, see pp. 27-28.

${ }^{3}$ As discussed in the third section, these debates emerged in response to Ross's (2001) classic study "Does Oil Hinder Democracy?," which presented the first cross-national statistical analysis of the political resource curse. I begin the reexamination with this study, finding that multiple imputation undermines its central finding that oil wealth (measured as fuel exports as a fraction of GDP) is negatively associated with levels of democracy.

"In the political science literature, the term "endogeneity" is sometimes used to refer more narrowly to reverse causation between the dependent and explanatory variables. I use the term in the traditional econometric sense, that is, to refer to situations in which the explanatory variable is correlated with the error term (of which reverse causation is merely one instance).
} 
consistent with Andersen and Ross's findings, indicates the existence of such a curse during a period that mostly coincides with or follows the wave of nationalizations.

The second debate concerns the effects of oil wealth on the stability of different types of political regimes. I find that multiple imputation casts doubt on evidence for Morrison's (2009) notable argument that oil and other nontax revenues reduce the probability of regime change in both dictatorships and democracies by enabling them to appease social groups that pose a threat to regime survival. Instead, it indicates that such revenues have "antidemocratic" effects, prolonging dictatorships but destabilizing democracies. Critically, however, such effects are once again restricted to the post-1980 period. These findings are substantiated by reanalyses of two important additional studies of the impact of oil wealth on regime stability: Ross's (2012) book "The Oil Curse," whose results were already in line with the findings; and Wright, Frantz, and Geddes's (2015) study of the mechanisms of autocratic regime survival, whose results were only partially consistent with the findings but become fully consistent when re-estimated.

The reexamination thus provides remarkably congruent evidence that there is a political resource curse, albeit only during the relatively recent period in which governments have controlled most of the rents generated by petroleum production. These findings both shed new empirical light on the existence and scope conditions of the political resource curse and suggest that a major reason different studies of this issue have produced conflicting results is that they have overlooked the problem of missing data.

\section{The Neglected Missing-Data Problem}

In this section, I provide a brief overview of the missing-data problem in statistical analyses of the political resource curse. The first part of the section discusses the specific methodological issues that arise when listwise deletion is used to deal with missing data 
in such analyses. The second part explains how multiple imputation can help to address these issues and hence improve the quality of statistical inferences.

\section{Listwise Deletion and Pro-Democracy Bias}

While scholars of the political resource curse are generally aware of the relatively high proportion of missing values in their datasets - a trend that I systematically document in the following section - they have paid surprisingly little attention to the potential methodological pitfalls of using listwise deletion to handle such values.5 The performance of listwise deletion in analyses of the political resource curse can be evaluated in terms of three basic statistical criteria: bias, efficiency, and the ability to yield reasonable estimates of uncertainty (Graham, 2009). With respect to efficiency, listwise deletion is always wanting: by discarding information contained in incomplete observations, it results in higher standard errors, wider confidence intervals, and reduced statistical power. Although it fares better on the third criterion - estimated standard errors are generally valid - this advantage is offset by losses in efficiency (Allison, 2002).

The bias caused by listwise deletion is a more complex issue that rests on the mechanism by which data become missing. Scholars usually distinguish between three such mechanisms (Little \& Rubin, 1987, 2002). Data are (1) missing completely at random (MCAR) if the probability that a given value is missing does not depend on any information in the dataset; (2) missing at random (MAR) if it depends on observed data only; and (3) missing not at random (MNAR) if it depends (at least in part) on missing data. 6 Listwise deletion produces unbiased inferences only when the MCAR assump-

\footnotetext{
${ }^{5}$ Efforts to address the problem of missing data have mostly focused on compiling new data sources, triangulating between existing ones, and identifying alternative treatments. While such efforts are highly valuable, they must be accompanied by the adoption of modern missing-data methods (such as multiple imputation) in order to avoid the statistical problems described in this section.

${ }^{6}$ More formally, if $Z$ denotes a dataset with an observed portion $Z_{\mathrm{obs}}$ and a missing portion $Z_{\mathrm{mis}}$, $M$ denotes a matrix of the same dimensions as $Z$ in which cells have a value of 1 if missing and $o$ otherwise, and $\phi$ denotes parameters from the joint distribution function of $Z$, MCAR can be expressed
} 
tion holds - that is, when omitting incomplete observations leaves a random sample of the data. Under MAR or MNAR, deleting such observations produces samples that are skewed away from units with characteristics that render them more likely to have missing data.

How do data on the political resource curse become missing? A first, crucial point is that the MCAR assumption is unlikely to be satisfied in any area of comparative politics or political science more generally. As Cranmer and Gill (2013) note, "It is difficult to think of a situation in political science, other than a computer malfunction, that would result in missing values being entirely unrelated to any attribute or political phenomena, observed or unobserved" (429). Indeed, in the next section I show that the MCAR assumption - which, unlike the MAR and MNAR assumptions, can be tested in practice - is violated in every study I reanalyze. In general, therefore, listwise deletion will tend to produce biased inferences in analyses of the political resource curse.

If missingness in datasets on the political resource curse is not completely random, what is it caused by? While the answer will vary from one dataset to another depending on its specific range of countries, years, and variables, one factor that tends to be important in almost all cases is a state's political institutions.7 Empirical studies have found that democracies are more likely to release policy-relevant socioeconomic data to the public and to international organizations than dictatorships (controlling for income and other variables) (Edwards, Coolidge, \& Preston, 2011; Hollyer, Rosendorff, \& Vreeland, 2011; Ross, 2006). 8 One potential explanation for this difference is that democratic leaders as: $p\left(M \mid Z_{\text {obs }}, Z_{\text {mis }}\right)=p(M \mid \phi) ; \operatorname{MAR}$ as $p\left(M \mid Z_{\text {obs }}, Z_{\text {mis }}\right)=p\left(M \mid Z_{\text {obs }}, \phi\right)$; and MNAR as $p\left(M \mid Z_{\text {obs }}, Z_{\text {mis }}\right)=$ $p\left(M \mid Z_{\text {obs }}, Z_{\text {mis }}, \phi\right)$.

7Other possible determinants of missingness include a state's size, economic system, bureaucratic capacity, investment inflows from foreign oil companies, and integration into global energy markets. The importance of these factors may vary by time period, making the latter another potential determinant. For instance, levels of missing data are likely to be higher for communist states during the Cold War, newly independent states in the 1960s, and almost all oil producers before the emergence of global energy markets in the 1990s.

${ }^{8}$ Interestingly, Ross (2006) argues that high-income autocracies are less likely to release such informa- 
have stronger incentives to adhere to popular demands for transparency because they can be removed from power (Hollyer, Rosendorff, \& Vreeland, 2011). Another is that democracies depend less on strong economic performance for their legitimacy and are thus less concerned about revealing the true state of the economy. It is also conceivable that democratic institutions embody norms of transparency and accountability that politicians externalize in their interactions with the international community 9 Regardless of the precise causal mechanism, measures of democracy are likely to be strongly related to the pattern of missing data.

The upshot is that applying listwise deletion to datasets on the political resource curse will often give rise to a selection problem that might be called pro-democracy bias. Since authoritarian states typically report fewer data, listwise deletion will tend to produce samples in which the most democratic nations in the dataset are overrepresented. The effect of this bias on estimates of the strength of the negative relationship between democracy and natural resource wealth will depend on the particular range of countries and years covered by the dataset. In some datasets, observations with lower levels of democracy will have higher levels of resource wealth, causing inferences based on listwise deletion to understate the strength of this relationship. In other datasets, less democratic observations will have lower levels of resource wealth, producing the opposite effect. In either case, as shown in the next section, pro-democracy bias has significant implications for our empirical understanding of the political resource curse.

tion than low-income ones because they rely less on the financial support of international organizations such as the International Monetary Fund and the World Bank, which demand data in return for assistance. In line with this argument, neither Edwards, Coolidge, and Preston (2011) nor Hollyer, Rosendorff, and Vreeland (2011) find a consistent relationship between per capita income and transparency.

9 Similar claims have been made about democratic norms of peaceful conflict resolution and compromise in the international relations literature on the democratic peace. 


\section{Addressing the Problem with Multiple Imputation}

How can multiple imputation address the shortcomings of listwise deletion in analyses of the political resource curse? Multiple imputation involves three key stages ${ }^{10}$ First, $m$ values are imputed for each missing cell, with variation across values reflecting uncertainty about the correct imputation model. Imputed values are independent draws from a posterior distribution of the missing data conditional on the observed data, typically derived from a parametric model that assumes the complete data are multivariate normal. ${ }^{11}$ Second, each of the $m$ complete datasets are analyzed. Due to the separation between the imputation and analysis stages, complete-data methods can be applied to each dataset, making this a straightforward task. Finally, the $m$ separate point estimates are combined into one using the "Rubin rules" (Rubin, 1987). These rules state that the pooled point estimate is equal to the average of the $m$ estimates, while its variance is equal to a weighted sum of the estimated variances within and between the $m$ datasets. ${ }^{12}$

Multiple imputation is substantially more efficient than listwise deletion because it (1) utilizes rather than discards data in incomplete observations and (2) allows analysts to incorporate extra information into the imputation model by including variables that are not in the analysis ("auxiliary variables"). Multiple imputation also performs at least as well as listwise deletion on the third criterion mentioned earlier as it reflects uncertainty about imputed values and thus yields valid estimates of standard errors. This is a major advantage over ad-hoc "single" imputation methods such as mean substitution, zero imputation, and linear interpolation. These methods produce downward-biased standard errors because they treat imputed values as "knowns" rather than probabilistic

\footnotetext{
${ }^{10}$ Multiple imputation was first proposed by the statistician Donald Rubin in the late 1970s and further developed with collaborators over the next decade (Little \& Rubin, 1987; Rubin, 1976, 1977, 1987; Rubin \& Schenker. 1986).

${ }^{11}$ While real data obviously do not always conform to multivariate normality, this model has been found to perform well even in the presence of violations (Rubin \& Schenker. 1986: Schafer. 1997).

${ }^{12}$ That is, for a given quantity of interest $\beta$ (say, a regression coefficient), $\dot{\beta}=\frac{1}{m} \sum_{i=1}^{m} \hat{\beta}_{i}$ and $\operatorname{var}(\hat{\beta})=$ $W+\left(1+\frac{1}{m}\right) B$, where $W=\frac{1}{m} \sum_{i=1}^{m} \operatorname{var}\left(\hat{\beta}_{i}\right)$ and $B=\frac{1}{m-1} \sum_{i=1}^{m}\left(\hat{\beta}_{i}-\hat{\beta}\right)^{2}$.
} 
estimates $\sqrt{13}$ They can thus be legitimately accused of "making up data" - a common misconception about multiple imputation. The goal of multiple imputation is in fact to preserve important features of the existing data (such as means, variances, and covariances) while capturing the uncertainty inherent in missing-data prediction.

Can multiple imputation address selection problems such as pro-democracy bias? Unlike listwise deletion, multiple imputation is unbiased when data are MAR as well as MCAR. Under MNAR, however, multiple imputation cannot avoid bias: since missingness depends (to some extent) on missing values, observed data alone do not provide the basis for a valid imputation process. Strictly speaking, real data are almost always MNAR, with missingness depending in part on observed data and in part on missing data (Graham, 2009). Critically, however, multiple imputation is not seriously biased under MNAR if missingness is strongly related to observed data and thus approximates MAR (Collins, Schafer, \& Kam, 2001; Graham, Hofer, \& MacKinnon, 1996: Schafer, 1997). The key question is thus: How much does missingness depend on observed data? ${ }^{14} \mathrm{Ob}-$ viously, this is not possible to directly measure because we do not actually have access to missing data. Nevertheless, if the dataset contains one or more variables that are highly correlated with missingness, it is reasonable to assume that multiple imputation will perform almost as well as under (pure) MAR. If there are no such variables, however, the technique may result in major bias - though, importantly, still no more than listwise deletion in almost all cases ${ }^{15}$ Indeed, even in this worst-case scenario multiple

${ }^{13}$ They also frequently produce biased point estimates (for different reasons in each case) (Little \& Rubin. 2002).

${ }^{14}$ As Graham (2009) argues, "Because all missingness is MNAR (i.e., not purely MAR), then whether it is MNAR or not should never be the issue. Rather than focusing on whether [multiple imputation's] assumptions are violated, we should answer the question of whether the violation is big enough to matter to any practical extent" (567).

${ }^{15}$ If the analysis model is a (correctly specified) regression of $Y$ on $X$, data for $X$ are MNAR, and missingness does not depend on $Y$, it is possible for listwise deletion to be less biased than multiple imputation. These conditions, however, are rarely satisfied in the real world (King et al. 2001: van Buuren. 2012). 
imputation is still the preferable of the two strategies due to its superior efficiency.

The implication is that multiple imputation can help to mitigate pro-democracy bias so long as variables that measure or are correlated with democracy are included in the dataset - which, of course, is always the case in analyses of the political resource curse 16 The precise extent of these gains in bias reduction will vary as a function of two factors. The first is the proportion of incomplete observations in the dataset. The higher this fraction, the greater the extent to which more democratic observations will be overrepresented in samples produced by listwise deletion and thus the greater the gains from keeping all observations in the sample through multiple imputation. The second is the number of variables in the dataset that are related to missingness. While all datasets on the political resource curse contain at least one such variable - i.e., a measure of democracy - higher numbers increase the degree to which missingness is related to observed data and thus lower the bias resulting from multiple imputation.

\section{Reexamining Previous Findings}

The preceding discussion suggests that in analyses of the political resource curse multiple imputation typically offers major gains in efficiency and bias reduction over listwise deletion (and almost never performs worse than it). This section investigates how substituting multiple imputation for listwise deletion affects the results of a number of influential empirical studies on the topic. I begin by providing an overview of missing-data patterns in these studies and describing the specific steps by which I implement multiple imputation. The rest of the section presents the results of the reanalysis in detail.

\footnotetext{
${ }^{16}$ Note that such variables are also correlated with the other potential determinants of missingness mentioned in fn. 7. (The time-series index in the dataset - normally Year - will capture temporal variation in the importance of these determinants and in missingness more generally.) Hence, multiple imputation will typically be capable of addressing a diverse range of selection problems.
} 


\section{Scope and Implementation}

I re-estimate the results of seven empirical studies on the political resource curse (see Table 1). These studies were selected for four reasons. First, most of them were conducted recently — all but one were published after 2008 - and can thus be said to represent "state-of-the-art" knowledge on the topic. Second, despite their novelty, they are widely cited in the academic literature and in many cases have also received considerable attention in policymaking circles ${ }^{17}$ Third, and closely related, they have each introduced significant theoretical and/or empirical innovations that have influenced subsequent studies and advanced our understanding of the political resource curse, as discussed in more detail later ${ }^{18}$ Finally, they contribute to arguably the two most prominent ongoing debates in the literature, namely, those concerning (1) whether there is statistical evidence for a political resource curse once we properly control for sources of endogeneity; and (2) how oil wealth affects the stability of different types of political regimes.

An examination of the studies' datasets and main empirical analyses reveals two important trends ${ }^{19}$ First, as shown in Table 1, they suffer from a severe missing-data problem. On average, almost one-quarter of the cells in the datasets are missing, with the figure exceeding 30 percent in three studies. The use of listwise deletion excludes more than 40 percent of eligible observations from the studies' analyses, causing the loss of 37 percent of available observed values ${ }^{20}$ As a result, a relatively large proportion of

\footnotetext{
${ }^{17}$ The studies have a combined citation count of more than 4,00o on Google Scholar (search performed 27 May 2016). Three of the studies published after 2008 - Haber and Menaldo (2011), Morrison (2009), and Ross (2012) - already have more than 300 citations each.

${ }^{18}$ One obvious candidate for inclusion is Tsui's (2011) study of the impact of oil discoveries on longterm democratic development, which, together with Ramsay (2011), pioneered the use of instrumental variables analysis in the literature. This study is excluded because it employs multiyear averages of timeseries variables - an ad-hoc and typically biased missing-data strategy (see previous section) - and thus contains a purely cross-sectional sample of 158 observations with almost no missing values.

${ }^{19}$ Three of the datasets were obtained from online data repositories (Morrison, 2009: Ross, 2001, 2012), one from an author's personal website (Haber \& Menaldo, 2011), and two through personal communications with authors (Ramsay, 2011: Wright, Frantz, \& Geddes. 2015).

${ }^{20}$ This is stark evidence of the inefficiency caused by listwise deletion. By preserving information in incomplete observations, multiple imputation utilizes an average of 93 percent more observed values in
} 
Table 1. Overview of Datasets in Reanalyzed Studies

\begin{tabular}{|c|c|c|c|c|c|c|c|c|}
\hline \multirow[b]{2}{*}{ Study } & \multirow[b]{2}{*}{$\begin{array}{l}\text { Missing } \\
\text { Cells (\%) }\end{array}$} & \multicolumn{4}{|c|}{ Main Empirical Analysis (\%) } & \multicolumn{3}{|c|}{$\begin{array}{l}\text { Polity Effect } \\
\text { on Inclusion }\end{array}$} \\
\hline & & $\begin{array}{l}\text { Cases } \\
\text { Omitted }\end{array}$ & $\begin{array}{l}\text { Existing } \\
\text { Data Lost }\end{array}$ & $\begin{array}{l}\text { Countries } \\
\text { Missing }\end{array}$ & $\begin{array}{l}\text { Years } \\
\text { Missing }\end{array}$ & MCAR & Sign & $p<0.01$ \\
\hline Ross 2001 & $33 \cdot 37$ & 41.84 & 37.21 & 26.75 & 15.63 & $x$ & + & $* * *$ \\
\hline Morrison 2009 & 32.65 & 78.52 & 69.84 & $44 \cdot 57$ & 32.56 & $x$ & + & $* * *$ \\
\hline $\begin{array}{l}\text { Haber \& Menaldo 2011/ } \\
\text { Anderson \& Ross } 2014\end{array}$ & 30.83 & 67.08 & 67.08 & 44.64 & 0.48 & $x$ & + & $* * *$ \\
\hline Ramsay 2011 & 2.97 & 22.77 & 21.79 & $5 \cdot 73$ & 0.00 & $x$ & + & $* * *$ \\
\hline Ross 2012 & $27 \cdot 12$ & 12.58 & 5.05 & 5.06 & 3.75 & $x$ & N.A. & \\
\hline $\begin{array}{l}\text { Wright, Frank, \& Geddes } \\
2015\end{array}$ & 13.89 & 27.08 & 18.51 & 18.57 & $7 \cdot 58$ & $x$ & N.A. & \\
\hline Average & 23.47 & 41.65 & 36.58 & 24.22 & 10.00 & & & \\
\hline
\end{tabular}

eligible countries in the datasets - almost one-quarter on average - are not just underrepresented but entirely omitted from the analyses. ${ }^{21}$ Naturally, levels of missingness and data loss vary across the studies, and are relatively modest in the case of Ramsay (2011) and Ross (2012). Nevertheless, it is noteworthy that in the majority of studies at least 27 percent of cells in the dataset is missing, 27 percent of eligible observations are excluded from the analysis, 22 percent of available observed data are lost, and 19 percent of eligible countries are completely discarded.

Is the missing-data problem in these studies unusually severe? To answer this question, I conducted a systematic review of missingness in a large sample of recently published comparative politics studies. Specifically, I sought to obtain the dataset of every cross-national quantitative study published during the three-year period 2013-15 incluthe datasets.

${ }^{21}$ As shown in the sixth column, the proportion of eligible years excluded is fairly low, but still exceeds 15 percent in two cases. 
sive in the American Political Science Review, the American Journal of Political Science, Comparative Political Studies, the Journal of Politics, and World Politics. ${ }^{22}$ Through searches of online data repositories and authors' personal websites, I was able to acquire 114 of the 231 datasets, a full list of which is provided in Table A1 of the online appendix (along with individual values of the statistics described below). ${ }^{23}$ On average, 14 percent of cells in the datasets were missing, more than 40 percent lower than the equivalent figure for the six political resource curse datasets ( 23 percent). Moreover, 61 percent of observations in the former datasets had at least one missing value (a rough proxy for how much information will be lost due to listwise deletion), compared with 90 percent in the latter ${ }^{24}$ This evidence strongly suggests that the missing-data problem in studies of the political resource curse is indeed more severe than in other areas of comparative politics (while indicating that such areas would also benefit from adopting more sophisticated missing-data methods).

The second trend is that the datasets are considerably better suited to multiple imputation than listwise deletion. The standard "Little's MCAR test," which evaluates a null MCAR hypothesis that observed variable means for subgroups of observations sharing the same missing-data pattern do not differ from expected population means based on maximum likelihood estimates, indicates that the the MCAR assumption is not satisfied in a single case (full test results are reported in Table A2 of the online appendix) ${ }^{25}$ Furthermore, missingness is strongly related to observed data. All the datasets contain a variable recording Polity scores, the standard measure of democracy in the literature. Moreover, the sample included in each study's main analysis has a substantially higher

\footnotetext{
${ }^{22}$ I excluded studies on the political resource curse (of which there were two).

${ }^{23} 56$ of the datasets were obtained from online repositories (in most cases the Harvard Dataverse Network) and 54 from personal websites.

${ }^{24} \mathrm{~A}$ small number of studies employ multiple datasets. In such cases, I averaged these statistics across all datasets.

${ }^{25}$ See Little 1988 ) for further details. The test was implemented using the mcartest command in Stata (version 13.1), which in some instances required removing highly collinear variables from the dataset.
} 
mean Polity score than the sample excluded from it (see Table A3) $^{26}$ While we cannot compare absolute means across studies because they are based on alternative versions of the Polity dataset and are scaled in different ways (as discussed in more detail below), the included sample means are on average 97 percent higher than the excluded ones. A Student's $t$-test shows that in each case these differences are statistically significant at the one percent level. 27

To more rigorously assess the extent to which missingness is related to democracy, for each study I estimated a logistic regression model in which the dependent variable is a dummy variable indicating whether or not a given observation is included in the main analysis and the regressor is a variable recording Polity scores. As indicated in Table 1, the coefficients on the latter variable are positive and significant at the one percent level in all studies. ${ }^{28}$ It is also important to note that in each dataset there were several other variables that had positive and significant coefficients when added to the regression model (including income, economic growth, public spending, and trade). In sum, any bias resulting from multiple imputation is likely to be small.

To implement multiple imputation, I use Honaker, King, and Blackwell's Amelia II program in $\mathrm{R}$, the most widely used multiple imputation software in political science. ${ }^{29}$ My implementation strategy follows the recommendations of the Amelia II's software manual, with a few small exceptions (Honaker, King, \& Blackwell, 2011). First, since Amelia II's expectation-maximization algorithm sometimes fails to converge when applied to large datasets, if the total number of variables exceeds 100 I exclude from the

\footnotetext{
${ }^{26}$ If the samples vary across estimations models in the main analysis, I take an average of the different sample means. Ross (2012) and Wright, Frantz, and Geddes (2015) are omitted from Table A2 because their analyses are restricted to either democracies or dictatorships.

27I separately calculate the gaps for each estimation model in the main analysis and combine the $p$ values using Fisher's method.

$28 \operatorname{Ross}(2012)$ and Wright, Frantz, and Geddes (2015) are again excluded for the reason mentioned in fn. 26 .

${ }^{29}$ The $m$ complete datasets generated by Amelia II are imported into Stata (version 13.1), where analysis results are aggregated using the built-in $m i$ command.
} 
imputation model all auxiliary variables that fail to meet the following two requirements: (1) they have a correlation of $r \geq 0.5$ with at least one analysis variable or at least one specially created dummy indicating whether observations for a given analysis variable are missing; and (2) less than 25 percent of their values are missing (since highly incomplete variables provide information at greater cost in terms of model size). 30

Second, I do not round off imputed values for categorical variables to the nearest discrete number, as this practice has been shown to produce biased parameter estimates 31 For the same reason, I also avoid applying logarithmic, square root, and logistic transformations to heavily skewed variables to normalize their distributions. $\sqrt{3^{2}} \mathrm{I}$ add only three features to the imputation model: (1) a sequence of third-order time polynomials to better model smooth temporal variation within cross-section units; (2) lags of the dependent and key explanatory variables (or leads if they are already lagged) since data for one period tend to be highly correlated with data for the previous (and subsequent) period; and (3) a ridge prior of one percent of the total number of observations, which addresses computational problems caused by high levels of missing data and multicollinearity.

Finally, I conduct more than the five imputations generally recommended by Amelia II's software manual (Honaker, King, \& Blackwell, 2011, 2). Recent statistical research has shown that conducting only five imputations frequently results in unacceptably weak statistical power, wide confidence intervals, and large Monte Carlo standard errors (i.e., errors across repeated runs of the same imputation process) (Bodner, 2008; Graham,

$3^{30}$ Similar rules have been proposed by Schafer (1997); White, Royston, and Wood 2011. The 100-variable threshold excludes the following four types of auxiliary variables, which are automatically omitted because they provide no extra information: (1) nonessential index variables; (2) items of composite variables; (3) dummies based on other variables; and (4) variables measuring data parameters such as means and variances.

$3^{1}$ This is because such values are typically not normally distributed around the cutoff point (for instance, 0.5 in the case of binary variables) (Allison, 2005: Cranmer \& Gill, 2013: Horton, Lipsitz, \& Parzen, 2003).

${ }^{32}$ Transforming skewed variables alters their relationship with other variables in the imputation model; in effect, it is equivalent to assuming that they have zero correlation with such variables (von Hippel, 2013). 
Olchowski, \& Gilreath, 2007; White, Royston, \& Wood, 2011). To avoid these problems, I set $m$ equal to the average missing-data rate of all variables in the imputation model 33

\section{Does Oil Really Hinder Democracy?}

I begin the reexamination by revisiting the findings of Ross's (2001) seminal article "Does Oil Hinder Democracy?" - one of the most influential studies in all of comparative political economy - which launched the debate over the political resource curse 34 To test the hypothesis that oil hinders democracy, which was first proposed by Middle East specialists in the 1970s but previously examined only in a handful of case studies, Ross analyzed pooled data on 157 countries in the period 1966-97 using a feasible generalized least squares model. The dependent variable Regime is measured using Polity98 scores (rescaled to run from o to 10), while the key explanatory variable Oil is measured as mineral-based fuel exports as a fraction of GDP. In addition, the model contains a lagged dependent variable, year dummies, and a host of control variables. The main results, reproduced in Table 2, are consistent with the political resource curse hypothesis: the coefficient on Oil is negative and statistically significant at the 1o percent level in all three specifications 35

While most variables in the analysis have relatively complete data, 40 percent of values for Oil are missing. Consequently, listwise deletion restricts us to using just 58 percent of eligible observations and discards 37 percent of observed data. This results in the complete exclusion of 42 of the 157 countries in the dataset. Importantly, observations included in the analysis differ systematically from those excluded, possessing higher levels of both Regime and Oil. These differences are illustrated graphically in the

\footnotetext{
${ }^{33} \mathrm{~A}$ similar rule is suggested by van Buuren (2012).

34The study has more than 2,500 Google Scholar citations and is listed as the most cited research article ever published in World Politics on the journal's official website (both searches performed 27 May 2016).

35The replicated results differ marginally from the published results because the author made corrections to the dataset before archiving it on the Harvard Dataverse Network.
} 
Table 2. Ross 2001: Resource Wealth and Democracy (Table 4)

\begin{tabular}{|c|c|c|c|c|c|c|}
\hline & \multicolumn{2}{|c|}{ Model 1} & \multicolumn{2}{|c|}{ Model 2} & \multicolumn{2}{|c|}{ Model 3} \\
\hline & Replicated & Imputed & Replicated & Imputed & Replicated & Imputed \\
\hline Regime (lagged) & $\begin{array}{l}0.267^{* * *} \\
(0.020)\end{array}$ & $\begin{array}{l}0.261^{* * *} \\
(0.017)\end{array}$ & $\begin{array}{l}0.239^{* * *} \\
(0.020)\end{array}$ & $\begin{array}{l}0.263^{* * *} \\
(0.016)\end{array}$ & $\begin{array}{l}0.242^{* * *} \\
(0.020)\end{array}$ & $\begin{array}{l}0.264^{* * *} \\
(0.016)\end{array}$ \\
\hline Oil & $\begin{array}{l}-0.030^{* * *} \\
(0.005)\end{array}$ & $\begin{array}{l}-0.007^{* *} \\
(0.003)\end{array}$ & $\begin{array}{l}-0.016^{* * *} \\
(0.005)\end{array}$ & $\begin{array}{l}-0.003 \\
(0.003)\end{array}$ & $\begin{array}{l}-0.011^{* *} \\
(0.005)\end{array}$ & $\begin{array}{l}-0.003 \\
(0.003)\end{array}$ \\
\hline Minerals & $\begin{array}{l}-0.043^{* * *} \\
(0.008)\end{array}$ & $\begin{array}{l}-0.012^{*} \\
(0.006)\end{array}$ & $\begin{array}{l}-0.028^{* * * *} \\
(0.007)\end{array}$ & $\begin{array}{l}-0.007 \\
(0.006)\end{array}$ & $\begin{array}{l}-0.028^{* * * *} \\
(0.007)\end{array}$ & $\begin{array}{l}-0.007 \\
(0.006)\end{array}$ \\
\hline Income (log) & $\begin{array}{l}0.920^{* * *} \\
(0.100)\end{array}$ & $\begin{array}{l}-0.000 \\
(0.000)\end{array}$ & $\begin{array}{l}0.712^{* * *} \\
(0.124)\end{array}$ & $\begin{array}{l}-0.000 \\
(0.000)\end{array}$ & $\begin{array}{l}0.684^{* * *} \\
(0.126)\end{array}$ & $\begin{array}{l}-0.000 \\
\text { (o.000) }\end{array}$ \\
\hline Islam & $\begin{array}{l}-0.019^{* * *} \\
(0.002)\end{array}$ & $\begin{array}{l}-0.015^{* * * *} \\
(0.002)\end{array}$ & $\begin{array}{l}-0.011^{* * *} \\
(0.003)\end{array}$ & $\begin{array}{l}-0.011^{* * * *} \\
(0.002)\end{array}$ & $\begin{array}{l}-0.015^{* * *} \\
(0.002)\end{array}$ & $\begin{array}{l}-0.012^{* * *} \\
(0.002)\end{array}$ \\
\hline OECD & $\begin{array}{l}1.395^{* * *} \\
(0.302)\end{array}$ & $\begin{array}{l}3.892^{* * *} \\
(0.269)\end{array}$ & $\begin{array}{l}1.469^{* * *} \\
(0.310)\end{array}$ & $\begin{array}{l}3.458^{* * * *} \\
(0.262)\end{array}$ & $\begin{array}{l}1.517^{* * *} \\
(0.312)\end{array}$ & $\begin{array}{l}3.483^{* * *} \\
(0.262)\end{array}$ \\
\hline Large & $\begin{array}{l}0.429 \\
(0.297)\end{array}$ & $\begin{array}{l}-0.556^{* * *} \\
(0.161)\end{array}$ & & & & \\
\hline Mideast & & & $\begin{array}{l}-2.792^{* * *} \\
(0.427)\end{array}$ & $\begin{array}{l}-1.272^{* * *} \\
(0.271)\end{array}$ & & \\
\hline SSAfrica & & & $-1.524^{* * *}$ & $-0.938^{* * *}$ & $-1.446^{* * *}$ & $-0.873^{* * *}$ \\
\hline Arabian Peninsula & & & & & $-3.439^{* * *}$ & $-1.223^{* * *}$ \\
\hline Constant & $\begin{array}{l}-3.313^{* * *} \\
(0.736)\end{array}$ & $\begin{array}{l}2.980^{* * *} \\
(0.233)\end{array}$ & $\begin{array}{l}-1.081 \\
(0.780)\end{array}$ & $\begin{array}{l}2.841^{* * *} \\
(0.196)\end{array}$ & $\begin{array}{l}-0.934 \\
(0.796)\end{array}$ & $\begin{array}{l}2.802^{* * *} \\
(0.196)\end{array}$ \\
\hline & $(0.736)$ & $(0.439)$ & $(0.780)$ & $(0.469)$ & (0.796) & $(0.469)$ \\
\hline $\mathrm{N}$ & 2181 & 3750 & 2181 & 3750 & 2181 & $375^{\circ}$ \\
\hline
\end{tabular}

Dependent variable is democracy (measured by Polity98 scores rescaled from o to 10). All righthand-side variables are lagged five years. Year dummies are estimated but not reported. Feasible generalized least squares regressions corrected for first-order autocorrelation with standard errors in parentheses. ${ }^{* * *} p<0.01,{ }^{* *} p<0.05,{ }^{*} p<0.1$.

upper-left panels of Figures 1 and 2, which plot the distribution of Regime and Oil, respectively, for included (black line) and excluded (gray line) observations. In each case, the distribution of excluded observations is concentrated at lower levels of the variable than the distribution of included observations. The implication is that autocracies that produce little or no oil — cases that do not provide evidence for the political resource curse hypothesis - are underrepresented in the analysis. This may cause it to overestimate the strength of the negative relationship between Oil and Regime.

Indeed, when the excluded observations are incorporated into the analysis through multiple imputation - which enables us to use 59 percent more observed values and 
Figure 1. Polity Scores of Observations Included in and Excluded from Main Empirical Analysis

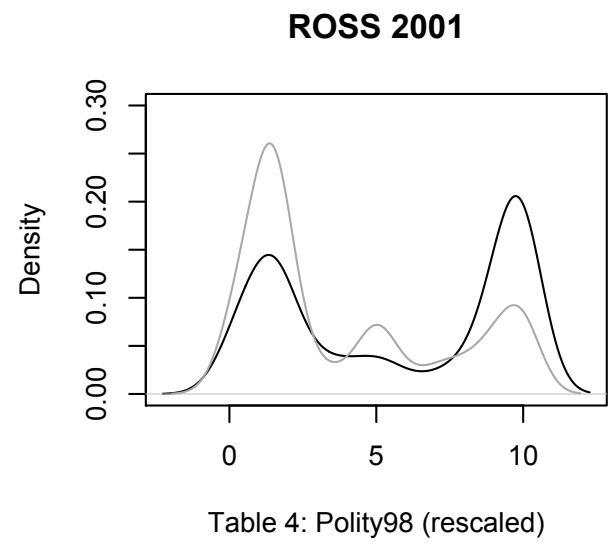

HABER AND MENALDO 2011

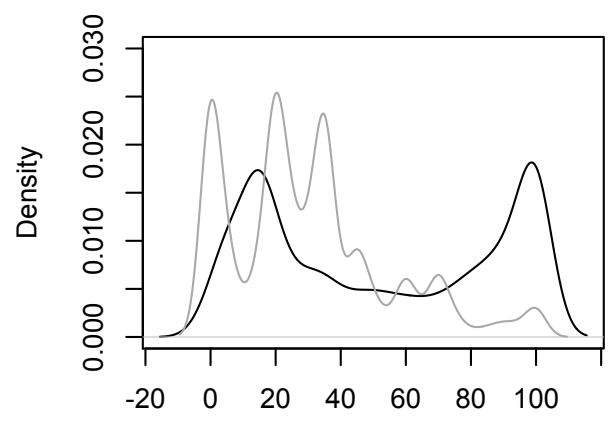

Table 5, Model 1: Polity II (normalized)

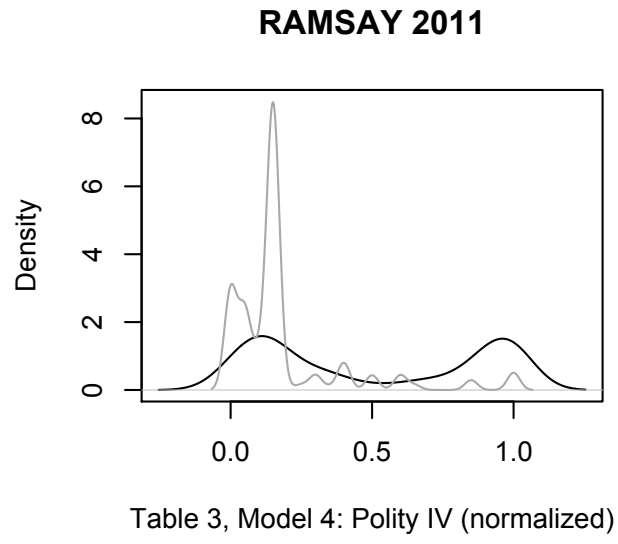

MORRISON 2009

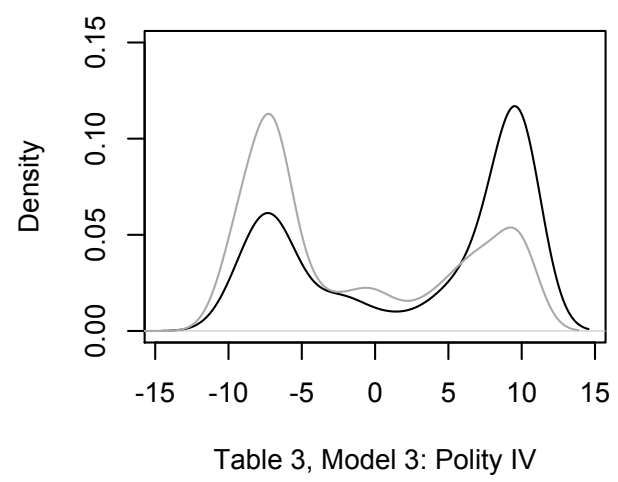

Table 3, Model 3: Polity IV

Included Observations

Excluded Observations

almost twice as many observations - support for the political resource curse hypothesis all but disappears. In Model 1, the coefficient on Oil shrinks to just one-fifth of its original size, though remains significant at the five percent level. In Models 2 and 3 , which include region dummies, the coefficient halves again and loses significance. In other words, once we control for the unobservable, time-invariant characteristics of an oil producer's region - or what Ross concisely calls "the region's history" (2001, 345) - we can no longer be confident that Oil has a strong negative relationship with Regime. 
Figure 2. Oil Wealth of Observations Included in and Excluded from Main Empirical Analysis

ROSS 2001

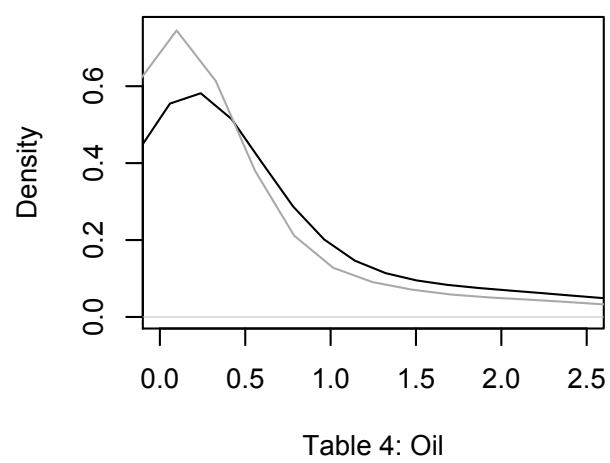

HABER AND MENALDO 2011

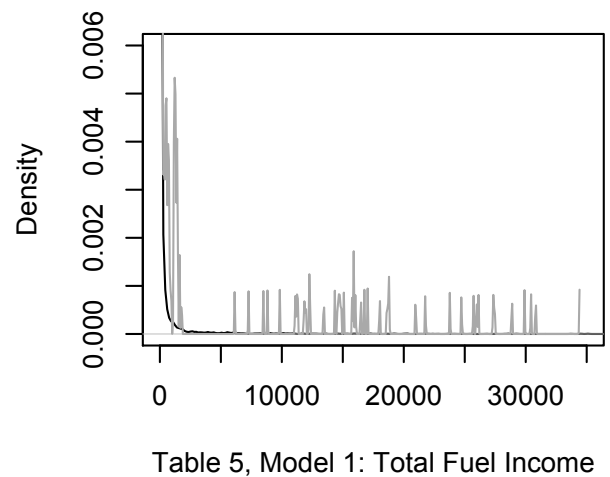

RAMSAY 2011

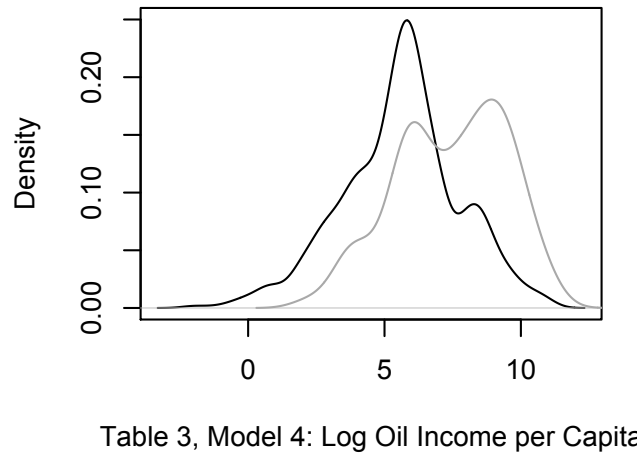

MORRISON 2009

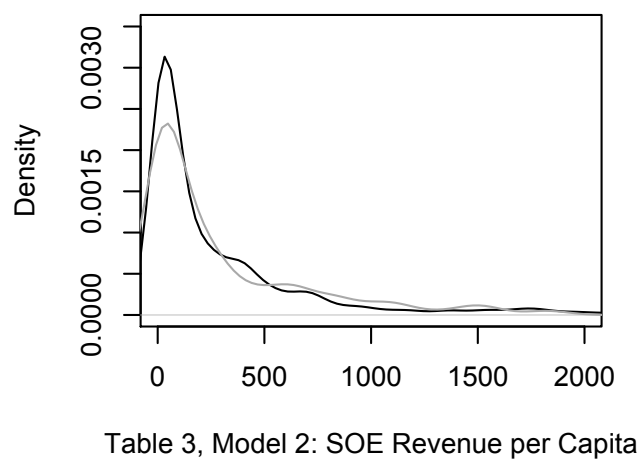

Included Observations

Excluded Observations

Since the article's publication, there have been a large number of follow-up studies that seek to address potential problems with its empirical analysis, generating a lively debate over the validity of the original finding. Do the conclusions of these more recent studies hold up when their results are re-estimated using multiple imputation? The rest of the section examines attempts to deal with two important issues: (1) endogeneity, which occurs when the explanatory variable is correlated with the error term; and (2) failure to distinguish between the effects of oil wealth on dictatorships and democracies. 


\section{The Conditional Effects of Oil on Democracy}

There are three potential sources of endogeneity in Ross's analysis: (1) measurement error with respect to Oil; (2) reverse causation between Regime and Oil, for instance, if oil prices respond to political changes or oil exports depend on income (because poorer countries consume less oil domestically), which is in turn influenced by regime type (Ross, 2008, 2012); and (3) perhaps most importantly, omitted variable bias resulting from a failure to properly control for unobserved country-specific heterogeneity.

In an innovative recent study, Ramsay (2011) attempts to address all three possibilities by employing an instrumental variables approach, which involves replacing the endogenous variable with an "instrument" that is correlated with it but uncorrelated with the error term (and thus does not directly affect the dependent variable). ${ }^{36}$ Specifically, Ramsay uses out-of-region natural disasters as an instrument for the total value of oil production per capita (rather than oil exports as a fraction of GDP), on the grounds that such events cannot influence regime type other than through their effect on the price of oil 37 Analyzing panel data on 48 oil producers in the period 1968-2002 using two-stage least squares regression, Ramsay finds evidence of a political resource curse. As shown in Table 3, the predicted values of Log Oil Income per Capita have a negative and significant relationship with (normalized) Polity IV scores. Unlike before, however, the results are robust to multiple imputation: while marginally declining in size, the coefficient on Log Oil Income per Capita remains negative and significant in all four replicated models.

What explains this difference? Ramsay's dataset, in contrast to Ross's, has a low

${ }^{36}$ Other innovative recent studies have sought to address the problem of reverse causation by conducting field experiments (de la Cuesta et al. 2015, Paler, 2013) and exploiting one-off exogenous shocks to oil income (such as the 1973 oil price spike) (Liou \& Musgrave, 2013). Alternative strategies for dealing with omitted variable bias include the use of extreme bounds analysis (Gassebner, Lamla, \& Vreeland. 2013), synthetic controls (Liou \& Musgrave, 2013), and, as discussed below, country fixed effects models.

37 As mentioned in $\mathrm{fn}$. 18, Tsui (2011) employed an instrumental variables approach to examine the political resource curse at a similar time to Ramsay, using estimates of oil endowments as an instrument for oil discoveries (the key determinant of oil wealth). For more recent applications of this approach, see Cotet and Tsui (2013); Kennedy and Tiede (2013). 
Table 3. Ramsay 2011: Two-stage Least Squares: Polity IV Scores on Oil Income (Table 3)

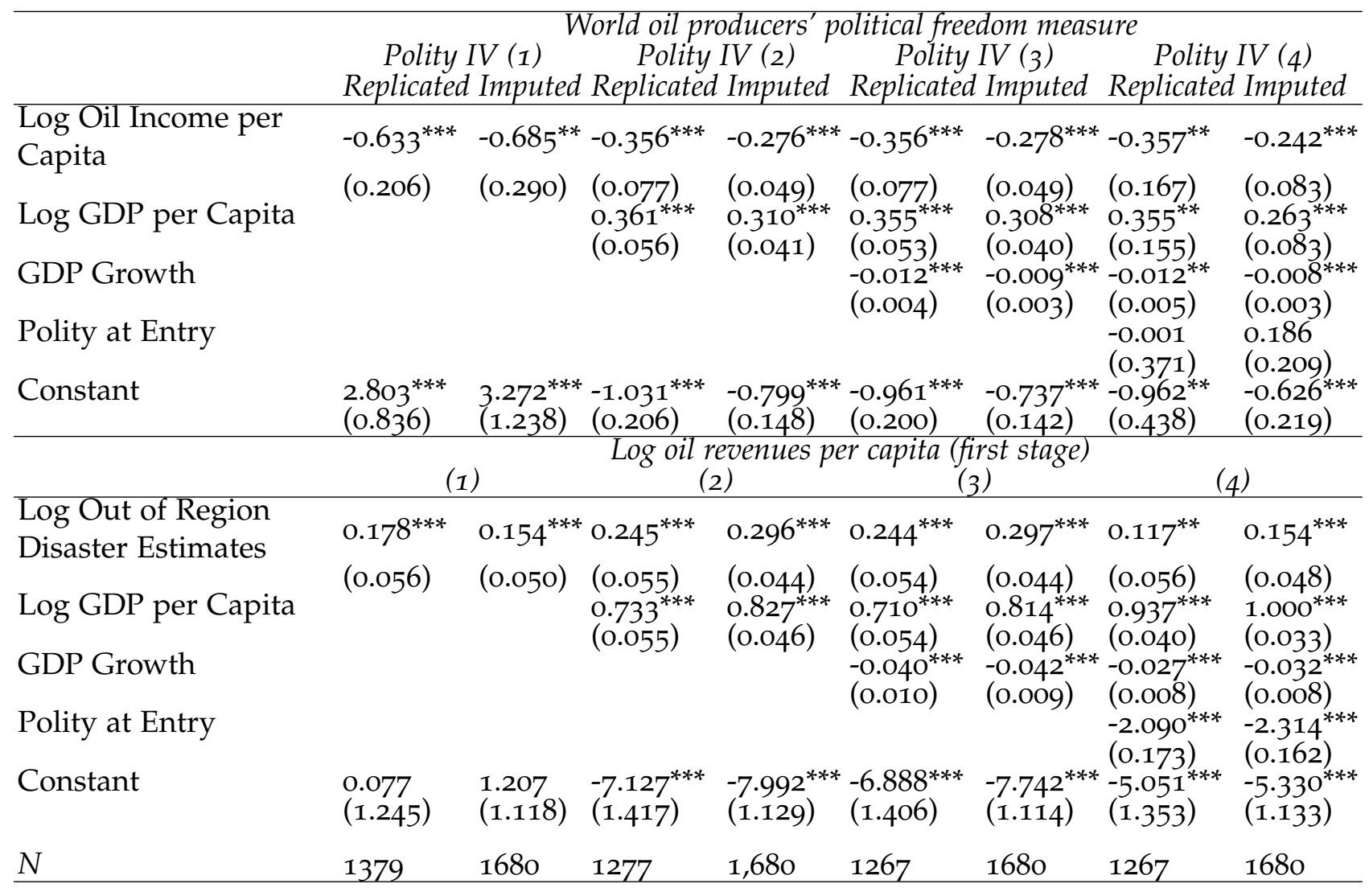

Dependent variable is level of democracy (measured using normalized Polity IV scores). Twostage least squares regressions with Newey-West heterosketastistic and autocorrelation-consistent standard errors in parentheses. ${ }^{* * *} \mathrm{p}<0.01 ;{ }^{* *} \mathrm{p}<0.05 ;{ }^{*} \mathrm{p}<0.1$.

rate of missingness, with more than 97 percent of cells observed (and 91 percent for the instrument Log Out of Region Disaster Estimates). As a result, listwise deletion omits a more modest 23 percent of eligible observations and 22 percent of observed values. This ensures that differences in levels of democracy and oil income between included and excluded observations (see the upper-right panels of Figures 1 and 2, respectively) are less likely to seriously bias inferences produced by listwise deletion.

Ramsay's findings, however, have not ended the debate due to doubts about the validity of his instrument. As Haber and Menaldo (2011) point out in an influential 
study, global oil price shocks are usually met with offsetting increases in production by major exporters, who have a policy of stabilizing prices. Thus, the instrument may be picking up a "big producer" fixed effect (and thus be correlated with the error term). To properly control for country-specific factors, Haber and Menaldo estimate an error correction model with country fixed effects using new data on 163 countries from 1800 to $2006 \sqrt{38}$ The results do not support the political resource curse hypothesis: oil income per capita and government reliance on resource revenues have a positive relationship with changes in Polity IV scores (normalized to run from o to 100) (see Table 4) 39

Haber and Menaldo's analysis has been challenged by Andersen and Ross (2014), who argue that it supports a conditional version of the political resource curse hypothesis that posits a negative relationship between oil wealth and changes in levels of democracy only after 1980. Indeed, when they add an interaction term between Total Oil Income and a dummy for the post-1980 period to the core fixed effects models, its coefficient is negative and significant (see Table 4) $4^{40}$ Andersen and Ross's explanation is that oil wealth only acquired antidemocratic properties following the widespread nationalization of petroleum industries during the 1970s, which transferred oil rents from international petroleum companies (most notably the so-called "Seven Sisters") to governments. ${ }^{41}$ This argument is consistent with the popular "rentier state" theory of the political resource curse, according to which oil rents alleviate social pressures for democratization by enabling governments to reduce taxes and increase spending on patronage (Beblawi \& Luciani, 1987; Mahdavy, 1970; Ross, 2001).

\footnotetext{
${ }^{38}$ The model also includes time fixed effects, a lagged measure of Polity (for error correction), and a number of control variables. Driscoll-Kraay standard errors are used to account for spatial heterogeneity.

${ }^{39}$ This relationship is statistically significant in the case of oil income per capita. For a similar finding, see Gurses (2009).

44 Aslaksen (2010) also finds support for the resource curse hypothesis in the presence of country fixed effects.

${ }^{41}$ The Seven Sisters were Anglo-Persian Oil Company (now BP), Gulf Oil, Mobil (now ExxonMobil) Royal Dutch Shell, Standard Oil of California (now Chevron), Standard Oil of New Jersey (also now ExxonMobil), and Texaco (now a subsidiary of Chevron).
} 
Table 4. Haber and Menaldo 2011: Error Correction Models; Andersen and Ross 2014: Replication of Haber-Menaldo ECM (Table 2)

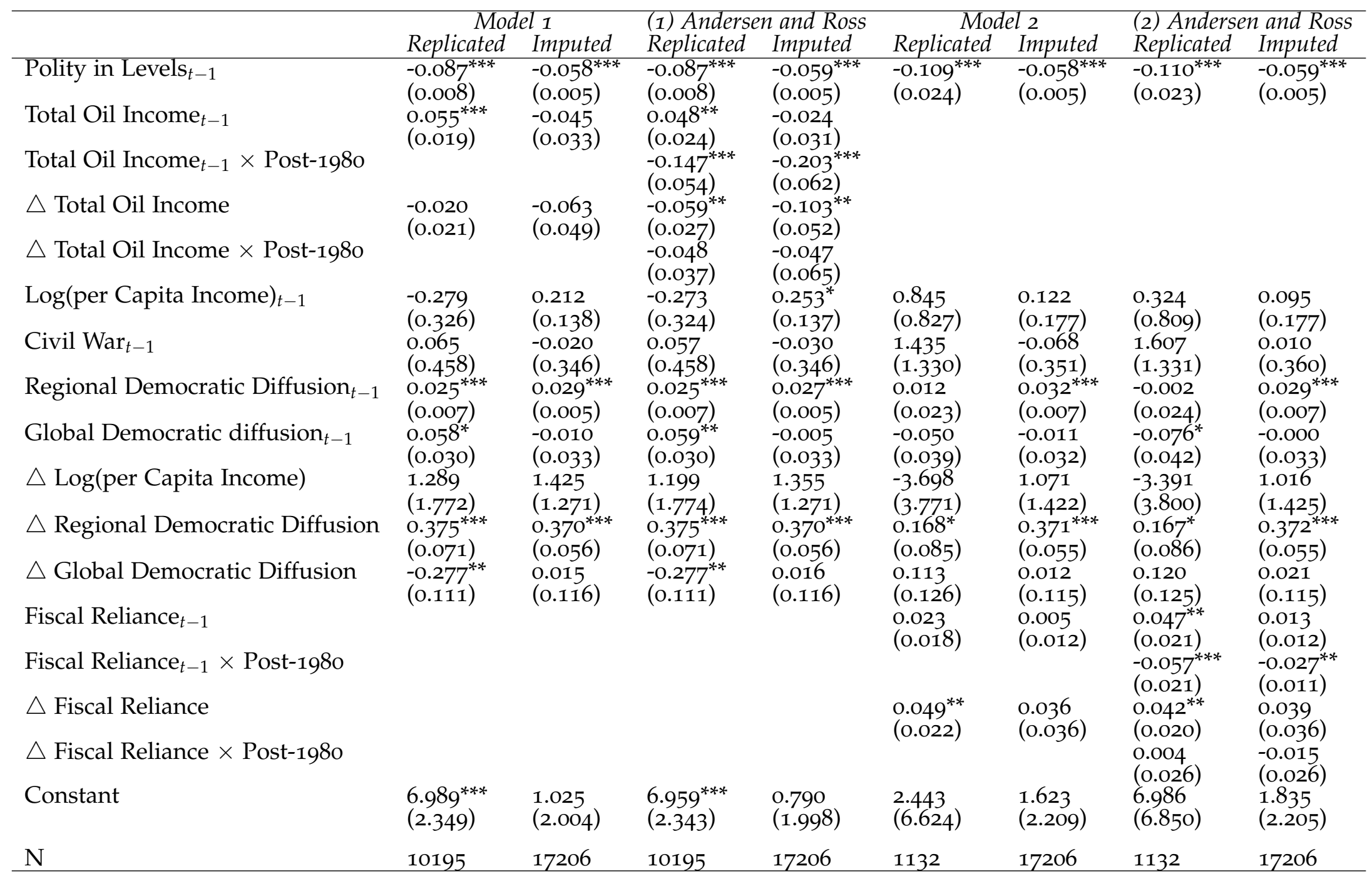

Dependent variable is change in democracy (measured by Polity IV scores normalized to run from o to 10o). Country and time fixed effects error-correction regressions with Driscoll-Kraay standard errors (estimated with Newey-West adjustment with one lag length) in parentheses. Separate country and year intercepts are not reported. ${ }^{* *} p<0.01,{ }^{* *} p<0.05^{*} p<0.1$. 
Haber and Menaldo's dataset is highly incomplete, with 31 percent of cells missing (and more than 50 percent for one-fifth of variables). Missing values for several variables are filled in using linear interpolation, which produces biased standard errors (see fn. 9) as well as biased point estimates when - as is common in comparative politics variables change smoothly over time or exhibit sharp deviations from a trend (Honaker \& King, 2010). Listwise deletion is applied to the remaining variables, resulting in the omission of 67 percent of eligible observations and the same proportion of observed data. Interestingly, excluded observations have lower levels of democracy but higher levels of resource income than included ones (see lower-left panels of Figures 1 and 2, respectively) ${ }^{42}$ Specifically, data on 33 oil-producing autocracies are omitted, including every major producer that has never democratized. This suggests that the analysis suffers from the opposite selection problem to Ross's: by excluding stable oil-rich autocracies, it is biased against finding a negative relationship between oil wealth and democracy.

The combination of this selection problem, the high proportion of missing data, and the use of two biased methods for handling such data ensures that multiple imputation alters the results substantially. As shown in Table 4, in Haber and Menaldo's original analysis the positive coefficient on Total Oil Income loses significance and turns negative, while the coefficient on Fiscal Reliance, which was not significant in the first place, shrinks to less than one-quarter of its original size 43 In Andersen and Ross's modified model, the coefficients on the interactions between these variables and the post-1980 dummy remain negative and significant, increasing by almost 50 percent in the case of Total Oil Income. The coefficients on the two variables themselves, meanwhile, drop out of significance, with that on Total Oil Income also turning negative. Interestingly, the

\footnotetext{
$4^{2}$ Figure 4 plots the distribution of total fuel income per capita, which contains elements of both Total Oil Income and Fiscal Reliance.

43I do not focus on Haber and Menaldo's longitudinal graphical analysis (see pp. 5-11) because they stress that it is merely suggestive, not providing the basis for causal inferences (since it does not control for any potentially confounding factors).
} 
latter change might be seen as even more consistent with the logic of Andersen and Ross's conditional argument, since governments would presumably derive at least some rents from oil wealth even before petroleum industries were nationalized (for instance, through corporate taxes and royalties) ${ }_{44}^{44}$ Finally, it is important to note that the results are also consistent with those of Ramsay's analysis, even though the latter did not explicitly test a conditional version of the political resource curse hypothesis: since Ramsay's panel begins in 1968, almost every year covered by the analysis is either during or after the wave of nationalizations.

\section{Is Regime Type a Conditioning Factor?}

The second issue with Ross's analysis is that it fails to distinguish between two possible scenarios: (1) oil wealth reduces the likelihood that dictatorships become democracies; and (2) oil wealth increases the likelihood that democracies become dictatorships (Ulfelder, 2007). One of the most notable attempts to disentangle these possibilities has been made by Morrison (2009), who argues that sources of nontax revenue such as oil make both dictatorships and democracies more stable by enabling them to pursue fiscal policies that appease social groups who pose a threat to regime survival. 45 In other words, oil does not have antidemocratic properties per se, but only stabilizing properties. Using a dataset on 184 countries in the period 1960-2002, Morrison tests this hypothesis by logistically regressing a binary measure of regime change on nontax revenue per capita and (separately) its three components, the largest of which is state-owned enterprise (SOE) revenue, the main form of oil rent for governments $\sqrt{46}$ The results bear

\footnotetext{
${ }^{44}$ Like Andersen and Ross, I place less weight on the Fiscal Reliance results because the data for this variable only cover 18 countries (and are thus almost entirely imputed in the reanalysis).

${ }^{45}$ Specifically, they enable democracies to lower taxes on wealthy elites and dictatorships to increase spending on poor citizens.

${ }^{46}$ The other two components are foreign aid and "other" nontax revenue, which mainly consists of government borrowing. The models also include a number of control variables.
} 
out the hypothesis: as shown in Table Ar of the online appendix, the coefficients on all measures of nontax revenue, including SOE revenue, are negative and significant 47

Morrison's dataset is highly incomplete, with one-third of cells missing (and onethird of variables possessing a missing-data rate of over 70 percent). Listwise deletion discards 79 percent of eligible observations and 69 percent of observed data, resulting in the complete exclusion of a remarkable 82 countries. Similarly to the previous case, included observations have lower levels of democracy but higher levels of SOE revenue than excluded ones (see lower-right panels of Figures 1 and 2, respectively). Unlike before, however, the excluded data comprise a large number of oil-producing states that underwent regime change away from democracy (and relatively few stable autocracies). Indeed, shifts toward autocracy in a remarkable 60 oil producers - including nine of the 20 largest today — are omitted from the analysis $44^{4}$ The results are thus likely to overestimate the stabilizing effects of oil rents and thus nontax revenues more broadly 49 Perhaps unsurprisingly, therefore, when the analysis is re-estimated with imputed data the coefficients on both the overall measure of nontax revenue and its SOE revenue component cease to be significant and fall to zero in the two core models (Models 1 and 2) (see Table A4) 50

While these results signal the absence of a strong negative relationship between nontax revenue and regime instability, they do not distinguish between dictatorships and democracies. In Table 5, therefore, I split the sample by regime type, focusing solely on Nontax Revenue per Capita and SOE Revenue per Capita. Surprisingly, in the sample

47Similar findings about oil revenues (rather than nontax revenues more broadly) have been reported by Dunning (2008); Smith (2004); Tsui (2011).

$4^{8}$ These countries make up almost one-third of the excluded observations. Stable autocracies, by contrast, account for just eight percent (and oil-producing ones six percent).

${ }^{49}$ Figure $\mathrm{A}_{1}$ in the online appendix indicates that levels of nontax revenue are also higher in excluded observations than included ones.

${ }^{50}$ The coefficients on the other two components of nontax revenue, whose values are also higher in excluded observations than included ones, experience similar changes. 
Table 5. Morrison 2009: Table 3 with Split Samples

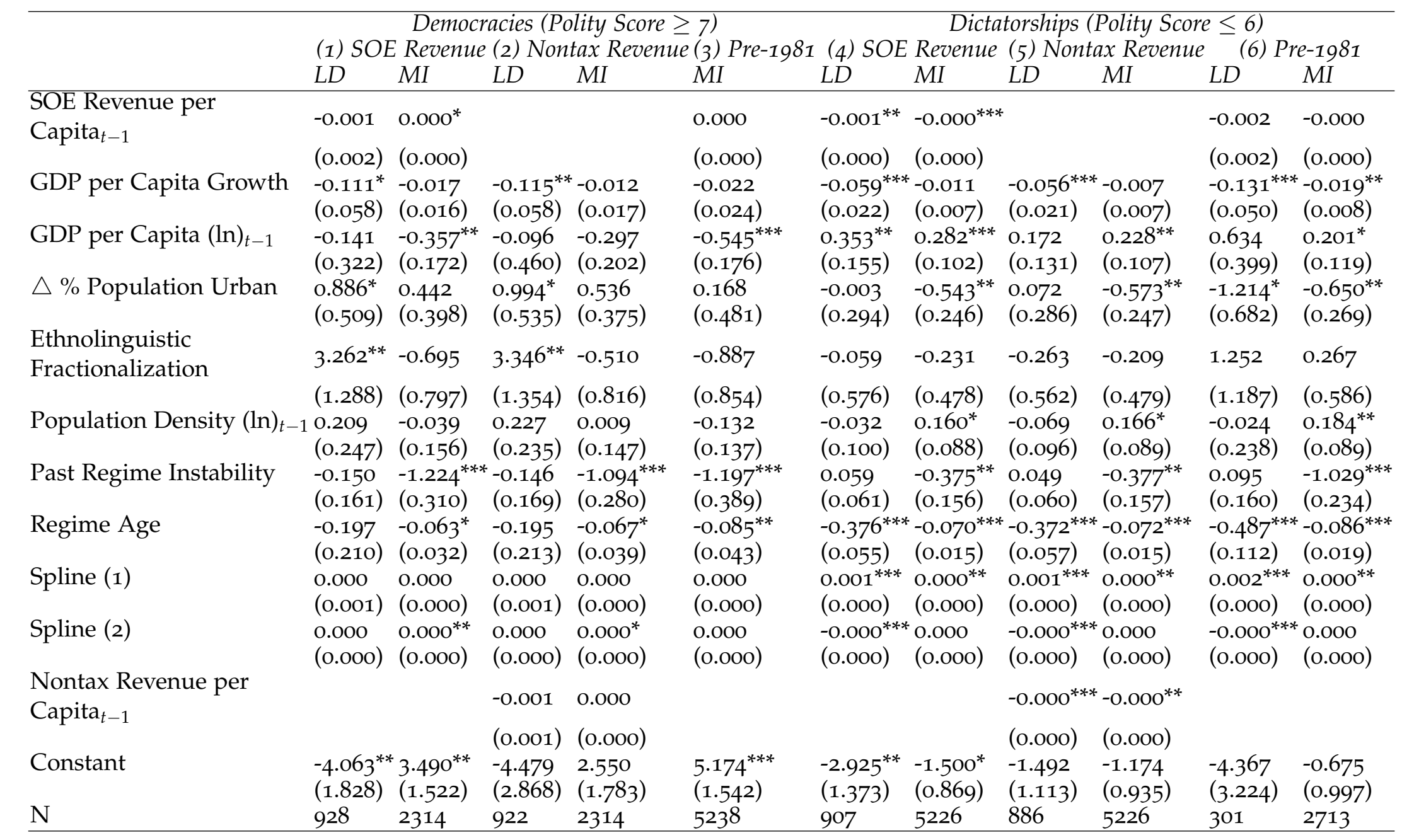

"LD" = listwise deletion; "MI" = multiple imputation. Dependent variable is regime instability (a dummy for whether a regime changes in a given year). Logistic regressions with standard errors clustered by country in parentheses. Replicated results for Model 3 are not provided because there are not enough observations in the original dataset to estimate the model. ${ }^{* *} \mathrm{p}<0.01$, ** $\mathrm{p}<0.05,^{*} \mathrm{p}<$ 0.1. 
restricted to democracies (Models 1 and 2) the coefficients on both variables are nonsignificant under listwise deletion. Under multiple imputation, the coefficient on $S O E$ Revenue per Capita becomes positive and significant, implying that oil undermines regime stability in democracies. The coefficient on Nontax Revenue per Capita remains nonsignificant and negative, however, suggesting that the other two components of the variable do not destabilize democracies 5 As expected, in the sample restricted to dictatorships (Models 4 and 5) the coefficients on the two variables are negative and significant under listwise deletion. In line with earlier results, these estimates are robust to multiple imputation (though the coefficients become slightly smaller). Critically, as shown in Models 3 and 6, the key findings are still subject to the earlier temporal condition: when the sample is restricted to the pre-1981 period, the coefficient on SOE Revenue per Capita is nonsignificant (with the same sign) in both democracies and dictatorships. 52

To examine the robustness of these findings, I reanalyze the results of two even more recent studies of the impact of oil wealth on regime stability that employ alternative measures and data sources. The first is Ross's (2012) important book "The Oil Curse," which separately analyzes regime change in dictatorships and democracies using a new dataset covering 174 countries from 1960 to 2000. The results, displayed in Table 6, are consistent with those reported above: oil income per capita has a negative and significant effect on the probability of a dictatorship democratizing (Panel 1) and a positive and significant effect on the probability of a democracy failing (Panel 2) - with the key exception of the period $1960-7953$ These results are virtually unchanged by multiple imputation, in large part due to the low level of missingness in the sample: only 8

\footnotetext{
${ }^{11}$ This difference is theoretically puzzling. One possible explanation is that it is easier to use oil and other SOE revenues to pursue antidemocratic ends because - unlike foreign aid and government borrowing they are purely domestic and thus come with no international scrutiny or pressure.

${ }^{2}$ Model 3 only displays the results based on multiple imputation because there were not enough observations in the original dataset to estimate the model.

53I exclude Model I from the original tables, which only includes control variables.
} 
Table 6. Ross 2012: Transitions to Democracy, 1960-2006 (Table 3.7); Transitions to Authoritarianism, 1960-2006 (Table 3.9)

(1) Dependent variable: Transition to democracy (dummy)

\begin{tabular}{|c|c|c|c|c|c|c|c|c|c|c|}
\hline & & 2) & (3) 1 & $960-79$ & (4) 198 & $80-2006$ & & & & (6) \\
\hline & Rep. & $\operatorname{Imp}$ & Rep. & Imp. & Rep. & $\operatorname{Imp}$ & Rep. & Imp. & Rep. & Imp. \\
\hline Income (log) & $\begin{array}{l}0.332^{*} \\
(0.171)\end{array}$ & $\begin{array}{l}0.158^{*} \\
(0.084)\end{array}$ & $\begin{array}{l}0.406 \\
(0.254)\end{array}$ & $\begin{array}{l}0.262 \\
(0.389)\end{array}$ & $\begin{array}{l}0.124 \\
(0.134)\end{array}$ & $\begin{array}{l}0.322 \\
(0.197)\end{array}$ & $\begin{array}{l}0.256 \\
(0.168)\end{array}$ & $\begin{array}{l}0.315 \\
\text { (o.194) }\end{array}$ & $\begin{array}{l}0.225 \\
(0.162)\end{array}$ & $\begin{array}{l}0.340^{*} \\
(0.202)\end{array}$ \\
\hline $\begin{array}{l}\text { Regime Duration } \\
(\log )\end{array}$ & -0.046 & $-0.214^{* *}$ & -0.122 & 0.151 & $-0.438^{* * *}$ & -0.132 & 0.010 & 0.049 & $0.387^{*}$ & $0.506^{* *}$ \\
\hline Oil Income (log) & $\begin{array}{l}(0.181) \\
-0.179^{* *} \\
(0.079)\end{array}$ & $\begin{array}{l}(0.101) \\
-0.126^{* * *} \\
(0.040)\end{array}$ & $\begin{array}{l}(0.303) \\
-0.078 \\
(0.114)\end{array}$ & $\begin{array}{l}(0.343) \\
0.074 \\
(0.174)\end{array}$ & $\begin{array}{l}(0.141) \\
-0.129^{* *} \\
(0.059)\end{array}$ & $\begin{array}{l}(0.193) \\
-0.202^{* *} \\
(0.091)\end{array}$ & $\begin{array}{l}(0.181) \\
-0.292^{* *} \\
(0.092)\end{array}$ & $\begin{array}{c}(0.152) \\
*-0.432^{* * *} \\
(0.111)\end{array}$ & $\begin{array}{l}(0.229) \\
-0.197^{* *} \\
(0.090)\end{array}$ & $\begin{array}{l}(0.197) \\
-0.372^{* * *} \\
(0.115)\end{array}$ \\
\hline $\begin{array}{l}\text { Oil Income (log) } \\
\times \text { Latin America }\end{array}$ & & & & & & & $0.673^{* * *}$ & $0.817^{* * *}$ & $0.414^{* * *}$ & $0.637^{* * *}$ \\
\hline Prior Democracy & & & & & & & $(0.152)$ & (0.179) & $\begin{array}{l}(0.143) \\
1.915^{* * * *} \\
(0.465)\end{array}$ & $\begin{array}{l}(0.188) \\
2.000^{* * *} \\
(0.526)\end{array}$ \\
\hline $\begin{array}{l}\text { Economic } \\
\text { Growth }\end{array}$ & & & & & & & & & $\begin{array}{l}-0.054^{* * x} \\
(0.017)\end{array}$ & $\begin{array}{c}* 0.064^{* * *} \\
(0.018)\end{array}$ \\
\hline $\begin{array}{l}\text { Muslim } \\
\text { Population }\end{array}$ & & & & & & & & & -0.720 & -0.776 \\
\hline$N$ & 3,507 & 4,239 & 1,297 & 1,715 & 2,210 & 2,524 & 3,507 & 4,239 & $\begin{array}{l}(0.551) \\
3,422\end{array}$ & $\begin{array}{l}(0.706) \\
4,239\end{array}$ \\
\hline
\end{tabular}

(2) Dependent variable: Transition to authoritarianism (dummy)

\begin{tabular}{|c|c|c|c|c|c|c|c|c|c|c|}
\hline & \multirow{2}{*}{\multicolumn{2}{|c|}{ (2) }} & \multicolumn{2}{|l|}{ (3) Belou } & \multicolumn{2}{|c|}{ (4) Ábove $\$ 5,000$} & \multicolumn{2}{|c|}{ (5) $1960-79$} & \multicolumn{2}{|c|}{ (6) $1980-2006$} \\
\hline & & & Rep. & Imp. & Rep. & Imp. & Rep. & $\operatorname{Imp}$ & Rep. & $\operatorname{Imp}$ \\
\hline $\begin{array}{l}\text { Regime Duration } \\
\text { (log) }\end{array}$ & $-0.342^{* *}$ & $-0.344^{* *}$ & -0.240 & -0.260 & $-0.892^{* *}$ & -0.786 & $-0.417^{*}$ & -0.367 & -0.280 & -0.320 \\
\hline & $(0.169)$ & $(0.164)$ & $(0.164)$ & (0.159) & $\left(0.45^{2}\right)$ & & $(0.242)$ & (o.237) & $(0.209)$ & (0.206) \\
\hline Income (log) & $\begin{array}{l}-0.717^{* *-} \\
(0.144)\end{array}$ & $\begin{array}{l}-0.704^{* *} \\
(0.135)\end{array}$ & $\begin{array}{l}-0.580^{* * *} \\
(0.177)\end{array}$ & $\begin{array}{l}-0.568^{* *} \\
(0.163)\end{array}$ & $\begin{array}{l}-2.48 \mathrm{O}^{* * *} \\
(0.651)\end{array}$ & $\begin{array}{c}-1.835^{* * *} \\
(0.692)\end{array}$ & $\begin{array}{l}-0.689^{* *} \\
(0.172)\end{array}$ & $\begin{array}{l}-0.693^{* *} \\
(0.174)\end{array}$ & $\begin{array}{l}-0.960^{* *} \\
(0.218)\end{array}$ & $\begin{array}{l}-0.948^{* * *} \\
(0.201)\end{array}$ \\
\hline Oil Income (log) & $\begin{array}{l}0.121^{* *} \\
(0.0564)\end{array}$ & $\begin{array}{l}0.123^{* *} \\
(0.056)\end{array}$ & $\begin{array}{l}0.113^{*} \\
(0.0630)\end{array}$ & $\begin{array}{l}0.123^{* *} \\
(0.061)\end{array}$ & $\begin{array}{l}0.129 \\
(0.174)\end{array}$ & $\begin{array}{l}0.133 \\
(0.183)\end{array}$ & $\begin{array}{l}0.0949 \\
\text { (o.117) }\end{array}$ & $\begin{array}{l}0.098 \\
(0.117)\end{array}$ & $\begin{array}{l}0.242^{* * *} \\
(0.0752)\end{array}$ & $\begin{array}{l}0.252^{* * *} \\
(0.077)\end{array}$ \\
\hline$N$ & 2,673 & 2,910 & 1,301 & 1,421 & 1,372 & 1,481 & 728 & 764 & 1,945 & 2,146 \\
\hline
\end{tabular}

"Rep." = Replicated; "Imp." = Imputed. Explanatory variables are lagged one year (with the exception of Prior Democracy). Panel I shows logistic regressions with robust standard errors in parentheses. Fiveyear period dummies not reported. Panel 2 shows rare-event logistic regressions with robust standard errors clustered by country in parentheses. ${ }^{* *} \mathrm{p}<0.01,{ }^{* *} \mathrm{p}<0.05,{ }^{*} \mathrm{p}<$ 0.1.

percent of data on Oil Income are missing, while the remaining variables in the analysis have an average missing-data rate of 11 percent. As a result, listwise deletion omits only 13 percent of eligible observations and 5 percent of observed values. 54

Ross's explanation for these results is that oil wealth stabilizes incumbents rather than

\footnotetext{
54I do not compare levels of democracy and oil income in included and excluded observations because the sample is restricted to either dictatorships or democracies.
} 
regimes, which in the case of democracies involves giving them sufficient resources to dismantle institutional constraints by "buying off" citizens with lower taxes and increased public spending (Ross, 2012, pp. 75-77).55 An interesting implication of this argument is that poor democracies will be more prone to failure because their institutions tend to be weaker and their citizens easier to buy off. Indeed, as shown in Panel 1 of Table 6, the coefficient on Oil Income ceases to be significant when the sample is restricted to countries with a GDP per capita above \$5,000 (Model 3), but remains significant - albeit only at the 1o percent level - when restricted to countries below this threshold (Model 4). As before, these results are robust to multiple imputation, with the coefficient in the latter model becoming significant at the five percent level. Hence, the antidemocratic effects of oil appear to be contingent upon income as well as time period.

The second study is Wright, Frantz, and Geddes's (2015) analysis of the effects of oil wealth on autocratic regime survival. Wright, Frantz, and Geddes seek to distinguish between two mechanisms by which oil wealth could enhance the stability of dictatorships: (1) lowering the chances of democratization (as indicated by the above results); and (2) reducing the risk of transition to subsequent dictatorship. They employ an innovative empirical strategy that also enables them to separate the between-country effects of oil wealth (i.e., the effects of cross-national variation in average levels of oil wealth) from the within-country effects (i.e., the effects of over-time changes in oil wealth in a single country) by conditioning the marginal effects of covariates on country means for explanatory variables. 56 They apply this strategy to a sample of 280 autocratic regimes in

55Similarly, a number of subnational studies have found that oil windfalls have pro-incumbent effects (Gervasoni, 2010; Goldberg, Wibbels, \& Mvukiyehe, 2008; Mahdavi, 2015).

${ }^{56}$ Most previous research solely examines between-country effects. A notable exception is Haber and Menaldo's study, which examines within-country effects in both dictatorships and democracies, though only in a subsidiary analysis whose results are reported in an online appendix. Wright, Frantz, and Geddes argue that Haber and Menaldo's choice of statistical model results in the exclusion of a large number of stable autocracies from the analysis and thus produces downward-biased estimates (a very similar selection problem to the one highlighted earlier). 
140 nations from 1945 to 2010, using Haber and Menaldo's data on oil income per capita. The results, displayed in Table 7 , indicate that oil income has a negative impact on the overall likelihood of autocratic regime failure (captured by the coefficient on $O i l_{t-1}$ ), but only negative between-country effects $\left(\overline{\mathrm{Oil}}_{i}\right)$ on the likelihood of democratization and within-country effects $\left(O i l_{d e v}\right)$ on the likelihood of autocratic transition,57

Wright, Frantz, and Geddes's dataset contains a moderate proportion of missing values: seven percent of cells are missing, with analysis variables possessing an average missing-data rate of 11 percent. Since almost 20 percent on values on the three dependent variables are missing, however, listwise deletion discards 25 percent of eligible observations and 20 percent of observed data, causing 32 countries to be entirely omitted from the analysis. $\sqrt[58]{5}$ When the results are re-estimated using multiple imputation, oil income continues to have a negative impact on the overall probability of autocratic regime failure, consistent with the reanalyzed results of the previous two studies. Interestingly, however, the within-country effects of oil income become negative and significant in the case of democratic transitions and remain so in the case of autocratic transitions. The between-country effects, meanwhile, become slightly weaker in the former but considerably stronger in the latter, only just exceeding the 1o percent significance threshold in both cases.59 Hence, there is fairly strong evidence that oil income has negative within-country and between-country effects on the likelihood of both democratization and autocratic transition. Once again, however, this finding only holds for the post-1980 period: when the sample is restricted to the years $1945-80$, the coefficients on $\overline{\mathrm{Oil}}_{i}$ and Oil $l_{d e v}$ cease to be significant (or close to the 1o percent threshold) in every model.

\footnotetext{
57I omit Models 2, 3, and 5 from the original table, which are restricted to autocracies that experience regime change (for the purpose of examining how excluding stable autocracies - like Haber and Menaldo's within-country analysis - affects the results).

${ }^{58}$ As with Ross (2012), I do not compare levels of democracy and oil income between included and excluded observations because the sample is restricted to dictatorships.

${ }^{59}$ The average $p$-value of the coefficients on $\overline{\mathrm{Oil}}_{i}$ is 0.13 in the case of democratic transitions (Panel B) and 0.16 in the case of autocratic transitions (Panel C)).
} 
Table 7. Wright, Frantz, and Geddes 2015: Oil Income and Autocratic Regime Survival (Table 1)

\begin{tabular}{|c|c|c|c|c|c|c|c|c|c|c|c|c|}
\hline & \multicolumn{4}{|c|}{ (1) Full } & \multicolumn{4}{|c|}{ (4) Full } & \multicolumn{4}{|c|}{ (6) Full } \\
\hline & \multicolumn{2}{|c|}{ All Years } & \multicolumn{2}{|c|}{$\begin{array}{c}\text { Pre-1981 } \\
L D \quad M I\end{array}$} & \multicolumn{2}{|c|}{ All Years } & \multicolumn{2}{|c|}{$\begin{array}{l}\text { Pre-1981 } \\
\text { LD } \quad M I\end{array}$} & \multicolumn{2}{|c|}{$\begin{array}{c}\text { All Years } \\
M I\end{array}$} & \multicolumn{2}{|c|}{$L D \begin{array}{r}\text { Pre-1981 } \\
M I\end{array}$} \\
\hline \multicolumn{13}{|c|}{ (A) All regime failures } \\
\hline $\mathrm{Oil}_{t-1}$ & $\begin{array}{l}-0.121 \\
(0.038\end{array}$ & $\begin{array}{l}-0.11 \\
\text { (0.06 }\end{array}$ & $\begin{array}{l}{ }^{*}-0.076 \\
(0.050\end{array}$ & -0.080 & & & & & & & & \\
\hline$\overline{\mathrm{Oil}}_{i}$ & & & & & $-0.111^{* *}$ & $\begin{array}{l}* 0.115 \\
(0.072)\end{array}$ & $\begin{array}{l}-0.057 \\
(0.049)\end{array}$ & -0.078 & $\begin{array}{l}-0.071^{* *} \\
(0.035)\end{array}$ & $\begin{array}{l}-0.103 \\
(0.074)\end{array}$ & 0.002 & $\begin{array}{l}-0.062 \\
(0.068)\end{array}$ \\
\hline$O i l_{d e v}$ & & & & & -0.166 & $\begin{array}{l}-0.131^{*} \\
(0.065)\end{array}$ & *-0.204 & -0.085 & $-0.290^{* *}$ & $-0.154^{*}$ & ${ }^{*}-0.307^{* *}$ & $\begin{array}{l}-0.086 \\
(0.111)\end{array}$ \\
\hline $\bar{Y}_{i}$ & & & & & & & & & $14.901^{* *}$ & * $5.574^{* * *}$ & $* 13.859^{* *}$ & $* 3.524^{* *}$ \\
\hline$N$ & 4,138 & 5,675 & 2,167 & 2,848 & 4,138 & 5,675 & 2,167 & 2,848 & $\begin{array}{l}(1.369) \\
4,138\end{array}$ & $\begin{array}{l}(1.692) \\
5,675\end{array}$ & $\begin{array}{l}(1.352) \\
2,167\end{array}$ & $\begin{array}{l}(1.5 \mathrm{OO}) \\
2,848\end{array}$ \\
\hline
\end{tabular}

(B) Democratic transitions

$\mathrm{Oil}_{t-1} \quad-0.153^{* * *}-0.121^{*}-0.171-0.086$

$\overline{\mathrm{Oil}}_{i} \quad-0.054 \quad(0.067)(0.106)(0.071)$

$\mathrm{Oil}_{d e v}$

$-0.224^{* * *}-0.125-0.215^{* *}-0.089-0.169^{* * *}-0.110-0.061 \quad-0.070$

$\begin{array}{lllllll}-0.07 \quad(0.077) & (0.108) & (0.074)(0.064) & (0.078) & (0.100) & (0.075)\end{array}$

$\bar{Y}_{i}$

$0.107-0.105^{*} 0.158-0.044-0.038-0.123^{*}-0.026-0.049$

-0.155 (0.063) (0.293) (0.116)(0.186) (0.066) (0.293) (0.116)

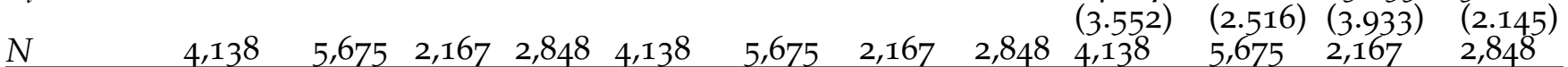

(C) Autocratic transitions

$\mathrm{Oil}_{t-1} \quad-0.055 \quad-0.110^{*}-0.043-0.074$

$\overline{\mathrm{Oil}}_{i} \quad(0.054) \quad(0.066)(0.067)(0.066)$

$O i l_{d e v}$

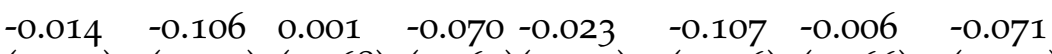

$(0.054)(0.075)(0.068)(0.069)(0.049) \quad(0.076)(0.066) \quad(0.070)$

$\bar{Y}_{i}$

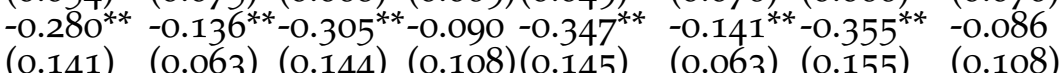

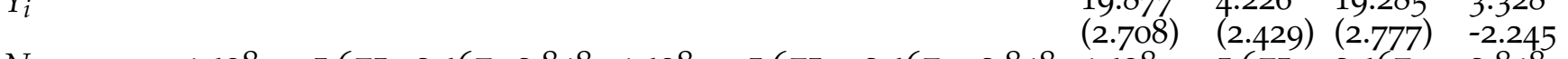

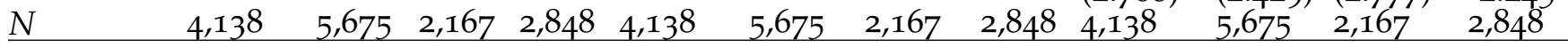

"LD" = listwise deletion; "MI" = multiple imputation. Dependent variable is the likelihood of regime failure in Panel A, transition to democracy in Panel B, and transition to autocracy in Panel C. Logistic regressions with standard errors clustered by country in parentheses. Time dependence polynomials, calendar time polynomials, and control variables (GDP per Capita, Civil War, Neighbor Democracy) included in all models but not reported. ${ }^{* *} \mathrm{p}<0.01,{ }^{* *} \mathrm{p}<0.05,{ }^{*} \mathrm{p}<0.1$.

In sum, multiple imputation does not support the claim that oil wealth enhances regime stability in democracies as well as dictatorships. Nor does it support studies that have found no relationship between oil wealth and democratic stability (Al-Ubaydli, 2012; Caselli \& Tesei, forthcoming; Ulfelder, 2007; Wiens, Poast, \& Clark, 2014). Rather, 
it suggests that oil wealth has antidemocratic effects, reducing the likelihood of regime change in dictatorships - both within and across countries - and increasing it in democracies. However, consistent with the findings of the previous subsection, such effects only occur in the post-1980 period (and may also be restricted to poor democracies).

\section{Conclusion}

Given the methodological sophistication of the ongoing debate over the political resource curse, it is puzzling that scholars have paid such little attention to the basic statistical issue of how to deal with missing data. This article has highlighted the methodological problems associated with the most common strategy for analyzing missing values in the political resource curse literature - listwise deletion - and shown that addressing these problems through the use of multiple imputation causes the results of a number of notable recent studies to converge on a key common finding: a political resource curse does exist, but only since the wave of petroleum industry nationalizations in the 1970s, which provided governments with greater access to the rents from oil production. This striking finding suggests that much of the disagreement over the political resource curse has been caused by a neglect of missing-data issues.

The finding is significant from a theoretical perspective, strengthening claims by Ross, Andersen, and others (e.g., Boschini, Pettersson, \& Roine, 2012; Luong \& Weinthal, 2010; Snyder \& Bhavnani, 2005) that the capacity of states to capture oil rents - a capacity that has varied considerably over time - is a critical determinant of whether oil wealth adversely affects democracy. Such arguments, in turn, contribute to an important broader research agenda that seeks to better understand the scope conditions of the political resource curse (for an overview, see Ross, 2015). This line of research has mostly focused on the conditioning effects of a state's initial regime type, which, as shown in 
the third section, are substantially weaker than commonly believed. Developing integrated theories of the political resource curse that can reconcile and illuminate different findings regarding scope conditions — such as Ross's recent (2012) theory of incumbent empowerment (see third section) - is an essential task for future research.

The results of the reexamination also have important implications for methodological practices in the political resource curse literature. Beyond the obvious implication that statistical analyses of this issue should adopt a more sophisticated approach to handling incomplete data, they suggest that scholars should generally be more explicit about how many missing values their datasets contain, how they deal with such values, and what consequences this choice may have for the validity of their inferences. The present situation is somewhat perverse: the studies that are least likely to provide such information are those using missing-data methods that require the most justification. The statistical and substantive importance of the changes brought about by multiple imputation suggests that the gains from adopting such practices could be substantial.

\section{References}

Ahmadov, Anar K. 2013. "Oil, Democracy, and Context: A Meta-Analysis." Comparative Political Studies 47 (9): 1238-1267.

Al-Ubaydli, Omar. 2012. "Natural resources and the tradeoff between authoritarianism and development." Journal of Economic Behavior and Organization 81 (1): 137-152.

Allison, Paul D. 2002. Missing Data. Thousand Oaks, CA: Sage Publications.

Allison, Paul D. 2005. "Imputation of categorical variables with PROC MI." Unpublished paper, Paper 113-30, 3oth Meeting of SAS Users Group International (SUGI 30). http: //www2.sas.com/proceedings/sugi30/113-30.pdf.

Andersen, Jørgen J., \& Michael L. Ross. 2014. "The Big Oil Change: A Closer Look at the Haber-Menaldo Analysis." Comparative Political Studies 47 (7): 993-1021.

Aslaksen, Silje. 2010. "Oil and Democracy: More Than a Cross-Country Correlation?" Journal of Peace Research 47 (4): 421-31.

Beblawi, Hazem, \& Giacomo Luciani, eds. 1987. The Rentier State. New York, NY: Crook Helm.

Bodner, Todd E. 2008. "What improves with increased missing data imputations?" Structural Equation Modeling 15 (4): 651-675. 
Boschini, Anne D., Jan Pettersson, \& Jesper Roine. 2012. "Resource Curse or Not: A Question of Appropriability." Scandinavian Journal of Economics 109 (3): 593-617.

Caselli, Francesco, \& Andrea Tesei. Forthcoming. "Resource Windfalls, Political Regimes, and Political Stability." Review of Economics and Statistics (to appear).

Collins, Linda M., Joseph L. Schafer, \& Chi-Ming Kam. 2001. "A Comparison of Inclusive and Restrictive Strategies in Modern Missing Data Procedures." Psychological Methods $6(4): 330-51$.

Cotet, Anca M., \& Kevin K. Tsui. 2013. "Oil and Conflict: What Does the Cross Country Evidence Really Show?" American Economic Journal: Macroeconomics 5 (1): 49-80.

Cranmer, Skyler J., \& Jeff Gill. 2013. "We Have to Be Discrete About This: A NonParametric Imputation Technique for Missing Categorical Data." British Journal of Political Science 43 (2): 425-449.

de la Cuesta, Brandon, Helen V. Milner, Daniel Nielson, \& Steve Knack. 2015. "No Greater Representation with Taxation: Experimental Evidence from Ghana and Uganda on Citizen Action toward Oil, Aid, and Taxes." Unpublished paper, Prepared for the Evidence in Governance and Politics (EGAP) meeting, Rice University, Houston, Texas, 23-24 October 2015. http://www.princeton.edu/ ${ }^{\mathrm{hmilner} / \text { working\% }}$ 20papers/NoGreaterRepresentationWithTaxation.pdf.

Dunning, Thad. 2008. Crude Democracy: Natural Resource Wealth and Political Regimes. New York, NY: Cambridge University Press.

Edwards, Martin S., Kelsey A. Coolidge, \& Daria A. Preston. 2011. "Who Reveals? Transparency and the IMF's Article IV Consultations." Unpublished paper, Seton Hall University Working Paper Series. http://wp.peio.me/wp-content/uploads/2014/04/ Conf5_Edwards-30.09.11.pdf.

Gassebner, Martin, Michael J. Lamla, \& James R. Vreeland. 2013. “Extreme Bounds of Democracy." Journal of Conflict Resolution 57 (2): 171-197.

Gervasoni, Carlos. 2010. "A Rentier Theory of Subnational Regimes." World Politics 62 (2): 302-240.

Goldberg, Ellis, Erik Wibbels, \& Eric Mvukiyehe. 2008. "Lessons from Strange Cases: Democracy, Development, and the Resource Curse in the U.S. States." Comparative Political Studies 41 (4-5): 477-514.

Graham, John W. 2009. "Missing Data Analysis: Making It Work in the Real World." Annual Review of Psychology 60: 549-76.

Graham, John W., Allison E. Olchowski, \& Tamika D. Gilreath. 2007. "How many imputations are really needed? Some practical clarifications of multiple imputation theory." Prevention Science 8 (3): 206-213.

Graham, John W., Scott M. Hofer, \& David P. MacKinnon. 1996. "Maximizing the Usefulness of Data Obtained with Planned Missing Value Patterns: An Application of Maximum Likelihood Procedures." Multivariate Behavioral Research 31 (2): 197-218.

Gurses, Mehmet. 2009. "State-sponsored development, oil and democratization." Democratization 16 (3): 508-529. 
Haber, Stephen, \& Victor Menaldo. 2011. “Do Natural Resources Fuel Authoritarianism? A Reappraisal of the Resource Curse." American Political Science Review 105 (1): 1-26.

Hollyer, James R., B. Peter Rosendorff, \& James Raymond Vreeland. 2011. “Democracy and Transparency." Journal of Politics 73 (4): 1191-1205.

Honaker, James, \& Gary King. 2010. "What to Do about Missing Values in Time-Series Cross-Section Data." American Journal of Political Science 54 (2): 561-81.

Honaker, James, Gary King, \& Matthew Blackwell. 2011. "Amelia II: A Program for Missing Data." Journal of Statistical Software 45 (7): 1-47.

Horton, Nicholas J., Stuart R. Lipsitz, \& Michael Parzen. 2003. "A Potential for Bias When Rounding in Multiple Imputation." The American Statistician 57 (4): 229-232.

Kennedy, Ryan, \& Lydia Tiede. 2013. "Economic Development Assumptions and the Elusive Curse of Oil." International Studies Quarterly 57 (4): 760-771.

King, Gary, James Honaker, Anne Joseph, \& Kenneth Scheve. 2001. "Analyzing Incomplete Political Science Data: An Alternative Algorithm for Multiple Imputation." American Political Science Review 95 (1): 49-69.

Liou, Yu-Ming, \& Paul Musgrave. 2013. "Refining the Oil Curse: Country-Level Evidence From Exogenous Variations in Resource Income." Comparative Political Studies 47 (11): 1584-1610.

Little, Roderick J.A. 1988. "A Test of Missing Completely at Random for Multivariate Data with Missing Values." Journal of the American Statistical Association 83 (404): 11981202.

Little, Roderick J.A., \& Donald Rubin. 1987. Statistical Analysis with Missing Data. New York, NY: Wiley.

Little, Roderick J.A., \& Donald Rubin. 2002. Statistical Analysis with Missing Data (Second Edition). Hoboken, NJ: Wiley.

Luong, Pauline J., \& Erika Weinthal. 2010. Oil Is Not a Curse: Ownership Structures and Institutions in Soviet Successor States. New York, NY: Cambridge University Press.

Mahdavi, Paasha. 2015. "Explaining the Oil Advantage: Effects of Natural Resource Wealth on Incumbent Reelection in Iran." World Politics 67 (2).

Mahdavy, Hussein. 1970. "The Patterns and Problems of Economic Development in Rentier States: The Case of Iran." In Studies in Economic History of the Middle East, ed. Michael A. Cook. London, UK: Oxford University Press , 428-67.

Morrison, Kevin M. 2009. "Oil, Nontax Revenue, and the Redistributional Foundations of Regime Stability." International Organization 63 (1): 107-38.

Paler, Laura. 2013. "Keeping the Public Purse: An Experiment in Windfalls, Taxes, and the Incentives to Restrain Government." American Political Science Review 107 (4): 706725.

Ramsay, Kristopher W. 2011. "Revisiting the Resource Curse: Natural Disasters, the Price of Oil, and Democracy." International Organization 65 (3): 507-529.

Ross, Michael. 2006. "Is Democracy Good for the Poor?" American Journal of Political Science 50 (4): 860-874.

Ross, Michael L. 2001. “Does Oil Hinder Democracy?" World Politics 53 (3): 325-61. 
Ross, Michael L. 2008. "But Seriously: Does Oil Really Hinder Democracy?" Unpublished paper, UCLA Department of Political Science. http://www.sscnet.ucla.edu/ polisci/faculty/ross/0il\%20and\%20Democracy\%20Revisited.pdf.

Ross, Michael L. 2012. The Oil Curse: How Petroleum Wealth Shapes the Development of Nations. Princeton, NJ: Princeton University Press.

Ross, Michael L. 2015. "What Have We Learned about the Resource Curse?" Annual Review of Political Science 18: 239-259.

Rubin, Donald B. 1976. "Inference and Missing Data (with Discussion)." Biometrika 63: 581-592.

Rubin, Donald B. 1977. "Formalizing Subjective Notions About the Effect of Nonrespondents in Sample Surveys." Journal of the American Statistical Association 72 (359): 538-43.

Rubin, Donald B. 1987. Multiple Imputation for Nonresponse in Surveys. New York, NY: John Wiley \& Sons.

Rubin, Donald, \& Nathaniel Schenker. 1986. "Multiple Imputation for Interval Estimation from Single Random Samples with Ignorable Nonresponse." Journal of the American Statistical Association 81 (394): 366-74.

Schafer, Joseph L. 1997. Analysis of Incomplete Multivariate Data. London, UK: Chapman and Hall.

Smith, Benjamin. 2004. "Oil Wealth and Regime Survival in the Developing World, 19601999." American Journal of Political Science 48, no. 2: 232-46.

Snyder, Richard, \& Ravi Bhavnani. 2005. "Diamonds, Blood, and Taxes: A RevenueCentered Framework for Explaining Political Order." Journal of Conflict Resolution 49 (4): 563-597.

Tsui, Kevin K. 2011. "More Oil, Less Democracy? Evidence from Worldwide Crude Oil Discoveries." The Economic Journal 121 (551): 89-115.

Ulfelder, Jay. 2007. "Natural Resource Wealth and the Survival of Autocracy." Comparative Political Studies 40 (8): 995-1018.

van Buuren, Stef. 2012. Flexible Imputation of Missing Data. Boca Raton: Taylor and Francis.

von Hippel, Paul T. 2013. "Should a Normal Imputation Model Be Modified to Impute Skewed Variables?" Sociological Methods and Research 42 (1): 105-138.

White, Ian R., Patrick Royston, \& Angela M. Wood. 2011. "Multiple imputation using chained equations: Issues and guidance for practice." Statistics in Medicine 30 (4): 377399.

Wiens, David, Paul Poast, \& William Roberts Clark. 2014. "The Political Resource Curse: An Empirical Re-evaluation." Political Research Quarterly 67 (4): 783-794.

Wright, Joseph, Erica Frantz, \& Barbara Geddes. 2015. "Oil and Autocratic Regime Survival." British Journal of Political Science 45 (2): 287-306. 